\title{
USING SOCIAL MEDIA AS A MANAGEMENT PLATFORM IN ICT4D $^{1}$
}

Adele Botha, a project manager in the Information Communication and Technology for Rural Education Development (ICT4RED) initiative in South Africa, pondered on what to do with the Twitter and Whatsapp data that had been secured over the course of the study. The data consisted of communication between people at the implementation sites and management of the ICT4RED initiative in the city of Pretoria.

Although Adele was based in Pretoria in a high-tech environment, the pilot project took place in the small village of Cofimvaba, which is situated in a deep rural area of the Eastern Cape Province where connectivity was not always guaranteed. The teachers and supervisors in Cofimvaba participated in occasional face-to-face meetings. This was supplemented by the online communication-amongst the teachers and the supervisors and with the management in Pretoria - that was conducted on Twitter and Whatsapp. These conversations formed the narratives that were thereafter analyzed using content analysis in order to find any information of benefit for the project. By making use of social media, the project team had secured a narrative of managerial communication. The Twitter feeds and the Whatsapp postings were analyzed using content analysis. Not only did this offer the benefits of a real time set of minutes of project communication and progress, it also established a company memory.

The downside of doing content analysis of the communications was that it was time-consuming and it required continuous involvement of Adele and other members of her team. Although the results of the first instance of content analysis of the managerial communications was rich and relevant, Adele was not convinced that the time-intensive content analysis procedure done by herself and her team really added enough value to justify the effort.

Adele recognized that one of the important benefits of continuing the analysis was that conflict resolution could be handled continuously. On the other hand doing the analysis manually was cumbersome and repetitive. How should she prioritize the possible benefits of continuing analysis against its obvious impact on her team's productivity and cost-effectiveness? Her decision involved a number of alternatives; 1) The project team could continue with the ongoing analysis of the Twitter and Whatsapp data 2) The analysis could be terminated, with ongoing dialogs being recorded and stored for later referencing purposes 3) The analysis could continue, but only through the use of one of the many available software packages designed to conduct such analysis unattended-with a likely commensurate decline in quality.

\footnotetext{
${ }^{1}$ Copyright (C) 2018, Abraham van der Vyver. This case was prepared for the purpose of class discussion. Names and some information have been disguised. This case is published under a Creative Commons BY-NC license and originally appeared as a chapter in Transforming Society Using ICT: Contemporary Discussion Cases from Africa. Permission is granted to copy and distribute this case for non-commercial purposes, in both printed and electronic formats.
} 


\section{Outline ICT4RED Initiative}

This case reflects on the way in which the monitoring and evaluation of managerial communication conducted on social platforms was carried out in the context of the ICT4RED initiative. ICT4RED was a large-scale pilot funded by the South African government. The aim of the pilot was improvement of the quality of teaching and learning in schools in the rural areas of the country. The site of implementation of the pilot was a district in the Eastern Cape Province of South Africa. The following quotation gives an outline of the project:

ICT4RED was one of the sub-projects of the over-arching Technology for Rural Education Development (TECH4RED) project, an effort between the Department of Science and Technology, the Department of Basic Education, the Department of Rural Development and Land Reform, and the Provincial Department of Education. TECH4RED was aimed at contributing to the improvement of rural education through technology-led innovation (Williams, Marais \& Rampa, 2013).

The ICT4RED implementation framework was an example of an evidence-based research project and subsequent piloting that was undertaken in authentic and challenging conditions, in order to determine what it would take to introduce tablets to rural schools in South Africa. The challenge going forward was to bridge the gap between science and practice, and thus ensure that the learning gained from the initiative improved future implementation efforts in the 'real world' (Ford, 2014).

\section{The Pilot Site}

The Republic of South Africa had many challenges in mathematics and science education at primary and high school levels. This was highlighted in reports such as the well regarded Trends in International Mathematics and Science Study (TIMMS) report of the International Association for Evaluation of Educational Achievement (Mullis, Martin, Gonzalez, et al, 1999). In terms of internet access in schools, South Africa also ranked poorly. The rural area of the Eastern Cape Province, where the pilot was implemented had many of these challenges in its education system.

Cofimvaba was one of the sites where the ICT4RED initiative was conducted. It was a small town in the deep rural area of the Eastern Cape Province of South Africa. The name was said to be have been derived from cofa, 'press', mvaba, 'milk-bag' (of goatskin). The pressing was done to break lumps of sour milk (HSRC, 1979).

The Provincial Eastern Cape Department of Education consistently struggled to overcome infrastructural and educational legacy issues. An initial baseline survey conducted by the CSIR (2012) found that $66 \%$ of the schools in the Cofimvaba district (which consisted of more than 350 schools) had unreliable or no access to water, $40 \%$ had unreliable or no access to electricity and that sanitation remained a challenge. At the time of the survey, the 26 schools in the Nciba Circuit, comprised of approximately 6,500 learners and 270 teachers. This translated to almost 30 learners per educator. Access to the internet and communication infrastructure was mostly unstable.

\section{Details of Implementation}

The initiative was carried out over three years between 2012 and 2015. Educators were trained on how to teach with technology and integrate mobile tablets in their classrooms using the Professional Teacher Development program. During this period, 360 teachers at 26 resource constrained schools in Cofimvaba, which was situated in the Nciba district of the Eastern Cape Province of South Africa, benefited from the project. 
The ICT4RED Initiative was part of a multi-stakeholder project. Participants were entangled in a complex matrix of managerial structures, which formed part of three national departments, one provincial department and one parastatal research agency. Whereas the government bodies were driven by bureaucratic principles, the researchers were bound by scientific guidelines. Organizational issues were managed in accordance with government policies and protocols. The research environment was highly populated by a myriad of researchers from universities and research agencies and this made project management and communication very difficult.

After analyzing a number of alternative communication platforms, Adele made provision for managerial communication via Twitter and Whatsapp in the management model. She also considered a number of teleconferencing platforms; however, the unstable connectivity besetting the region tilted the scale in favour of the other two options. Whatsapp was selected because of its ability to establish and archive a multi-way conversation and Twitter because of the conciseness of the communication enforced in this social media platform. Twitter's short message service (SMS) delivery system only allowed for 140 characters, spaces included, and this facilitated speedy and to-the-point communication. Whatsapp was on the other hand used as the primary communication channel. However, since Whatsapp only made provision for 100 participants per conversation, Twitter was added as a backup platform.

For the benefit of the projects, the Whatsapp narratives and the Twitter postings (tweets) were downloaded and analyzed. Adele was aware that electronic analysis software was also available to identify themes and keywords. While such an electronic analysis could potentially fast track the data gathering process, it would still not eliminate the need for review by a person.

The applications required for the execution of the project needed fairly stable connectivity. Adele was satisfied that reasonable connectivity was available to all the stakeholders. These levels of connectivity were also a prerequisite for accessing the e-textbooks that served as one of the empowerment tools of the project.

\section{The Decision}

The decision Adele faced was whether to continue the content analysis process, which she and the research team conducted on the narratives generated from the social media communications. She faced the following options and arguments.

\section{Analyze content from both platforms}

Adele could decide to leave the analysis process unchanged and continue to conduct content analysis on the Whatsapp narratives as well as the Twitter feeds. This option had cost implications in that she and two of her co-researchers had to allocate time to analyze the texts. Although she was both surprised and satisfied with the results she obtained so far, she was not sure if the great amount of time needed for content analysis were justified.

\section{Analyze content from only one platform}

If Adele decided to continue the analysis on only one platform, the question she faced was which one to discard. She had no doubt that each platform contributed a unique set of inputs to the managerial processes. She decided to document the pros and cons of the communication on each platform. 
Her view was that Whatsapp generated a fluent, less-formal narrative that contributed to a positive communication climate. The downside was that it often resulted in the loss of focus with participants exchanging comments about sideshows.

As far as Twitter was concerned, she felt that the Twitter's limitation associated with its short message service (SMS) delivery system (limited to 140 characters, spaces included) generated a much more focused conversation. She felt that the participants realized they had to stick to the topic at hand to get their messages on record.

\section{Do not do any content analysis}

Since clear communication channels had been established, Adele considered not continuing with content analysis at all. She felt that the participants were in agreement on the objectives and the methods of the project and that a favourable communication climate had been established. The project was entering the next phase in which coordination and conflict resolution could be established by way of interpersonal communication.

\section{Biography}

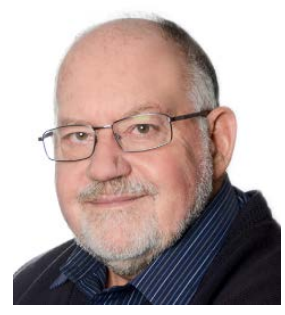

Dr Abraham van der Vyver is a Senior Lecturer at Monash University, South Africa. He has since 2005 used telecentres as field work hubs for research on e-democracy and e-governance. His interest resulted in an awarding of a 2009 Monash UniversitySichuan University collaborative research grant during for this project. He has also conducted research in the fields of social informatics and online communities.

\section{References}

Ford, M. 2014. ICT4RED Implementation Framework. Designing and implementing an Information Communication Technology for Rural Education Development (ICT4RED) initiative in a resource constrained environment: Cofimvaba School District, Eastern Cape, South Africa. M Herselman \& A. Botha (eds.). Pretoria: CSIR.

HSRC. (1979). Dictionary of Southern African place names. HSRC: Pretoria.

Mullis, I. Martin, M. Gonzalez, EJ. Gregory, KD. Garden, RA. O’Connor, KM. Chrostowski, SJ. \& Smith, T. TIMSS 1999 international mathematics report: findings from IEA's report of the third international mathematics and science study. Chestnut Hill: Boston College.

Williams, B., Marais, M. and Rampa, M. 2013. Evaluation design of the Cofimvaba e-textbook initiative. Unpublished Project Report. 


\section{Exhibit 1: WhatsApp Transcript Illustrating Coding and Categorization}

14:35, 19 Jul - Mario Marais: Hlengiwe changed the subject to "ICT4REDft” [Agenda setting]

13:18, 29 Jul - Mario Marais: Hlengiwe joined [Connective]

10:22, 31 Jul - Maggie Verster: The link to tonights webinar room is

http://meet78641452.adobeconnect.com/ict4red/ see u at 7 [Directional]

10:25, 31 Jul - Maggie Verster: We have made some nice changes to the mod so it is nb that everybody pops in. [Informational] [Motivational]

10:28, 31 Jul - +27 83450 8153: Omashani nearly shocked me she wrote 30th at her email whereas I know today [Intra-personal]

10:29, 31 Jul - +27 83414 9936: Oi..sorry everyone. ..I had tested this with hlengi yesterday and hence the wrong date... [Explanatory ]

10:30, 31 Jul - +27 83414 9936: Btw...there is an adobe connect app..click the link and your phone will take you through setup ..ie if it is possible through your device [Technological]

10:31, 31 Jul - Maggie Verster: Will check on that [Managerial]

10:37, 31 Jul - Benita Williams: Easy peasy to download the app and get access to the room! Maggie, will you say something about the $\mathrm{m}$ and e happy sheets at the end of each booklet? [Motivational]

[Coordinating]

10:38, 31 Jul - Maggie Verster: Absolutely, its in the ppt [Confirming] [Informational]

10:39, 31 Jul - Benita Williams: You are so organised! [Personal] [Expressive]

10:39, 31 Jul - +27 82850 5844: I've already downloaded the app from Play Store. You are right Benita. Its easy. [Informational] [Motivational]

10:39, 31 Jul - Maggie Verster: Scared of the mice? [Humor]

10:41, 31 Jul - +27 83414 9936: Trainers need softcopy of printed manuals .Maggie can you email?

[Requirement] [Managerial]

06:39, 04 Aug - Merryl Ford: Fantastic! What a STAR! [Expressive] [Personal]

07:20, 04 Aug - Roy Kattukkanal: I can meet you on monday night. [Arrangement]

07:12, 05 Aug - Maggie Verster: Do anyone know where the satelite coordinates are of the schools? I cant remember how to get to ntshingine. [Inquiry] 
21:22, 04 Aug - +27 76079 9949: Nite Senzo, we just started a whatsup group for Mgcawezulu, still one teacher though [Announcement ] [Reservation]

17:42, 05 Sep - +27 78438 3750: Hey guys I'm really sorry but I won't be able to make it for the webinar as I have a church function to attend. [Declarative] [Explanatory]

17:43, 05 Sep - +27 83327 6256: You can listen to the recording later. [Problem solving]

21:20, 04 Aug - +27 82850 5844: Done at the centre. Going to rest now. [Closing] 


\section{Exhibit 2: Excerpts from Twitter Transcript}

\section{Twitter analysis}

A number of examples of how the Twitter analysis was conducted are now provided:

Tweet: Teachers will receive 10" tablet with $3 G$ capability

Source: ICT4RED

Content type: Text

Managerial content: Directive

Communication type: Declarational

Tweet: Just finished testing more than 21 different tablets based on our min specs. Sadly very few passed

Source: ICT4RED

Content type: Text

Managerial content: Evaluation

Communication type: Declarational

Tweet: We have a committed, passionate team of people who are determined to make a success

Source: MF

Content type: Text

Managerial content: Mission

Communication type: Declarational

Tweet: Main aim is a model that can be replicated

Source: MF

Content type: Text

Managerial content: Objective

Communication type: Declarational

Tweet: Thank you to Arthur Mfebe teachers for your support in fine-tuning and testing our ideas - you are the best

Source: ICT4RED

Content type: Text

Managerial content: Felicitation

Communication type: Emotional

Tweet: Proud RT. The only way to win the hearts and minds of today's teens

Source: MV 
Content type: Picture

Managerial content: Student activity

Communication type: Emotional

\section{Managerial content types in Twitter}

The managerial content types that are represented in Twitter communication are listed and quantified in Table 1.

Table 1. Managerial content types

\begin{tabular}{|l|l|l|}
\hline MANAGERIAL & NUMBER & PERCENTAGE \\
\hline Informational & 15 & $30 \%$ \\
\hline Declarational & 12 & $24 \%$ \\
\hline Motivational & 10 & $22 \%$ \\
\hline Emotional & 4 & $8 \%$ \\
\hline Philosophical & 2 & $4 \%$ \\
\hline Explanatory & 2 & $4 \%$ \\
\hline Evaluative & 1 & $4 \%$ \\
\hline Political & 2 & $2 \%$ \\
\hline Humorous & 1 & $4 \%$ \\
\hline
\end{tabular}




\section{Managerial communication types}

The various managerial communication types that were identified in the Twitter strands are embedded in Table 2.

Table 2. Managerial communication types.

\begin{tabular}{|l|l|l|}
\hline Communication & Number of tweets & Percentage \\
\hline Announcement & 8 & $16 \%$ \\
\hline Milestone & 3 & $6 \%$ \\
\hline Objective & 3 & $6 \%$ \\
\hline Policy & 3 & $6 \%$ \\
\hline Evaluation & 2 & $4 \%$ \\
\hline Explanation & 2 & $4 \%$ \\
\hline Gratification & 2 & $4 \%$ \\
\hline Philosophy & 2 & $4 \%$ \\
\hline
\end{tabular}

